\title{
Transitional Pathways towards Achieving a Circular Economy in the Water, Energy, and Food Sectors
}

\author{
Dhesigen Naidoo ${ }^{1,2}$, Luxon Nhamo ${ }^{1, *(\mathbb{C}}$, Shenelle Lottering ${ }^{2}$, Sylvester Mpandeli ${ }^{1,3}$, Stanley Liphadzi ${ }^{1,4}$, \\ Albert T. Modi ${ }^{2}$ (D) Cristina Trois ${ }^{5}$ and Tafadzwanashe Mabhaudhi ${ }^{2, *(D)}$ \\ 1 Water Research Commission of South Africa (WRC), Lynnwood Manor, Pretoria 0084, South Africa; \\ dhesn@wrc.org.za (D.N.); sylvesterm@wrc.org.za (S.M.); stanleyl@wrc.org.za (S.L.) \\ 2 Centre for Transformative Agricultural and Food Systems (CTAFS), School of Agricultural, Earth and \\ Environmental Sciences, University of KwaZulu-Natal, Pietermaritzburg 3209, South Africa; \\ SewellS@ukzn.ac.za (S.L.); ModiAT@ukzn.ac.za (A.T.M.) \\ 3 Faculty of Science, Engineering and Agriculture, University of Venda, Thohoyandou 0950, South Africa \\ 4 School of Environmental Sciences, Research and Innovation, University of Venda, \\ Thohoyandou 0950, South Africa \\ 5 School of Engineering Sciences, University of KwaZulu-Natal, Durban 4000, South Africa; Troisc@ukzn.ac.za \\ * Correspondence: luxonn@wrc.org.za (L.N.); Mabhaudhi@ukzn.ac.za (T.M.)
}

Citation: Naidoo, D.; Nhamo, L.; Lottering, S.; Mpandeli, S.; Liphadzi, S.; Modi, A.T.; Trois, C.; Mabhaudhi, T. Transitional Pathways towards Achieving a Circular Economy in the Water, Energy, and Food Sectors. Sustainability 2021, 13, 9978. https:// doi.org/10.3390/su13179978

Academic Editor: Maria João Rosa

Received: 30 July 2021

Accepted: 1 September 2021

Published: 6 September 2021

Publisher's Note: MDPI stays neutral with regard to jurisdictional claims in published maps and institutional affiliations.

Copyright: (c) 2021 by the authors. Licensee MDPI, Basel, Switzerland. This article is an open access article distributed under the terms and conditions of the Creative Commons Attribution (CC BY) license (https:/ / creativecommons.org/licenses/by/ $4.0 /)$.

\begin{abstract}
Achieving sustainable socio-economic development requires approaches that enhance resource use efficiencies and can address current cross-sectoral challenges in an integrated manner. Existing evidence suggests an urgent need for polycentric and transformative approaches, as global and local systems have come under strain. This study conducted a systematic literature review at the global level to assess the progress made towards achieving a circular economy between 2010 and 2020, a period covering the formulation of the Sustainable Development Goals (SDGs) and the initial five years of their implementation. The focus was on the potential of improved water and energy use efficiency, linking them to food production within the context of a circular economy. Identifying successes, opportunities, challenges, and pathways towards a circular economy from the literature review facilitated developing a conceptual framework to guide strategic policy formulations towards a more sustainable economy. A combination of transformative approaches is analysed in an integrated way in response to the 2030 global agenda on sustainable development. Thus, the study is informed by the initiatives to attain SDGs and mitigating negative environmental impacts due to waste and pollution. The premise is to enhance transformational change as a catalyst for employment creation and the attainment of a green economy while reducing waste. Transformative approaches have been identified to provide pathways towards global climate targets and protection of the environment from further degradation. They are a catalyst to achieve SDG 12 on ensuring sustainable consumption and production patterns.
\end{abstract}

Keywords: linear models; cleaner production; sustainability; resource use efficiency; adaptation; waste reduction

\section{Introduction}

The urgent need to balance industrial development, the environment, social wellbeing, and economic growth is critical to achieving sustainability by 2030 [1-3]. As a result, efficient resource use and low-carbon emission strategies are crucial for promoting sustainable development and enhancing countries' overall economic growth $[4,5]$. Recent developments have shown that contemporary challenges require integrated and transformative approaches such as nexus planning, circular economy, sustainable food systems, and scenario planning that consider cross-sectoral interventions [2,6,7]. Of note is that these transformative approaches complement each other in their application as one informs or enhances the other or vice-versa $[3,7,8]$. In particular, the circular economy concept 
has gained prominence amongst policymakers, academics, community of practice, and environmentalists in response to the need to achieve sustainable development in the midst of challenges related to resources insecurity [1,9-11]. Transitioning from linearity to circularity is key for enhancing transformational change and sustainable resource management, particularly in the water, energy, and food sectors [4,12-14].

Transformative approaches have become influential in socio-economic and environmental research and policymaking, particularly during these unprecedented times when economies have taken a massive strain from the COVID-19 pandemic, compounded by climate change-related impacts [2]. Traditional linear economic models are increasingly acknowledged as inadequate in responding to the various "wicked problems" of the 21st century, which cascade from one sector to another $[2,15,16]$. Past experiences have shown that focusing on one sector results in suboptimal efficiencies in a single sector at the expense of others, thus aggravating the challenges in other sectors, creating maladaptation as challenges are just transferred to other sectors $[2,17,18]$. Therefore, identifying approaches linked to sustainability and operationalising these approaches to address economic and environmental challenges are important in integrated resource management that leads to circularity and a green economy $[3,13]$.

One transformative approach that has quickly gained prominence, the circular economy, is an alternative approach to achieving economic development, environmental protection, and resource security $[19,20]$. The circular economy is a sustainable development strategy envisaged to reduce waste and address the challenges related to environmental degradation and resource scarcity $[8,21,22]$. Its multi- $R$ principles include reducing, reusing, recycling, recovery, rethinking, and redesigning materials through enhanced resource use efficiency $[8,23]$. The concept is developed around the idea that all materials must be recycled, keeping them in use for longer periods $[9,24,25]$. All energy has to be derived from renewable sources; all activities must support and rebuild the ecosystem and support human and environmental health, and resources are used to generate value stages $[24,26,27]$. Thus, the circular economy is an approach that reduces waste by circulating them within the same system for the longest possible time through smarter product designs and circular business models $[8,28]$, and therefore, is critical for the attainment of the Sustainable Development Goals (SDGs), particularly the circular economy-related goal, the SDG 12 (ensure sustainable consumption and production patterns) [29]. Therefore, just like other transformative approaches, adopting the circular economy enhances the security of essential water, energy, and food resources [30,31].

There are, therefore, broad interlinkages and interrelationships between the circular economy and water, energy, and food resources [32-34]. There is also a general acknowledgment that achieving the circular economy is dependent on efficient use and recycling of resources [35-37]. The intricate interrelationship between the circular economy and the three resources (water, energy, and food) is based on that food systems are regarded as one of the most polluting systems, playing a significant role in greenhouse gas (GHG) emissions and environmental degradation [38,39]; the widely used thermal energy is the major catalyst of climate change $[40,41]$; wastewater recycling is considered to play an important role in ensuring water security [42,43]. The interrelations link the circular economy SDG (Goal 12) with Goal 2 (end hunger, achieve food security and improved nutrition and promote sustainable agriculture), Goal 6 (ensure availability and sustainable management of water and sanitation for all), Goal 7 (ensure access to affordable, reliable, sustainable, and modern energy for all), with broad linkages to the remaining other 13 SDGs. These extensive interrelationships call for holistic and transformative approaches in addressing sustainability goals and achieving the circular economy [3,44-46]. However, there is a need to mainstream circular models in strategic policy formulations to achieve the circular economy in a globe dominated by linear models that have shown to have reached their limitations as they encourage waste in the environment [2,47].

Furthermore, the increasing demand for resources necessitates this transformational change due to accelerated population growth, urbanisation, and economic development, 
balancing demand, and supply $[45,48,49]$. On the other hand, climate extremes continue to degrade water, energy, and food resources, particularly in semi-arid and arid regions across the globe $[43,48]$. Water reuse is a viable option but has not been explored fully as an alternative to sufficient water supply [50,51]. As already alluded to, the food sector contributes significantly to environmental degradation and GHG emissions $[39,52]$. The transition to a circular economy creates a unique opportunity to create synergies to adopt water reuse technologies, renewable energy sources, and sustainable food systems as an alternative to water, energy, and food security. Critical to this is the importance of transformative approaches in considering the risks and opportunities and synergies, and trade-offs before adopting waste recycling technologies and environmentally friendly sources of energy $[13,53]$. However, transitioning from linear approaches to circular and integrated models requires policy shifts coupled with sound financial backup $[3,45,54,55]$. Due to the intricate interlinkages between water, energy, and food sectors, transformational change is possible by applying transformative approaches like nexus planning, particularly the water-energy-food (WEF) nexus, to enhance synergies and overall resource use efficiency, and sustainable management and development $[3,44]$. Rapid urbanisation and the increasing middle class have increased demand for water, energy, and food resources [56,57]. Currently, two-thirds of the global energy consumed contributes to $80 \%$ of greenhouse gas emissions [58]. All this is happening when the urban population continues to grow and is projected to increase to 6.9 billion people by 2025 , which would account for $70 \%$ of the global population [59]. Thus, adopting the circular economy would enhance resource use efficiency, reduce waste, and use renewable energy sources by recovering materials and recycling waste into clean energy and minimising the trade-offs between economic growth, society, and the environment [60].

Therefore, the essence of the circular economy approach is to enhance resource use efficiency and ultimately resource security. This is vital for augmenting sustainability in the water, energy, and food sectors and facilitating coherent policy formulations that lead the adaptation and resilience. However, most studies discuss the circular economy in the context of cleaner production and reducing the environmental impact and waste production along the life cycle of a product [61-63]. Little has been done on the opportunities and challenges within the water, energy, and food sectors, particularly their role in transitioning into the circular economy. A systematic review of the literature was conducted to assess the progress on achieving the circular economy between 2010 and 2020, covering the planning phase in formulating the SDGs in 2015 and the first assessment phase of implementation (2015 to 2020). The premise was to assess progress and enhance the initiatives aimed at achieving SDGs $[6,64]$. This culminated in developing of a conceptual framework to guide strategic policy formulations towards a more sustainable economy and a greater environmental and human health.

\section{Methods}

\subsection{Literature Review}

The review was conducted following the general principles of the Preferred Reporting Items for Systematic Reviews and Meta-Analyses (PRISMA) systematic review process (Figure 1) [65,66]. The literature was downloaded from web-based search engines, including Google Scholar, Web of Science, and Scopus. Search words were associated with the Boolean operators "OR and "AND" using the following search criteria: "circular economy" OR "resource use" OR" efficiency" AND "sustainability" and 2010-2020. 


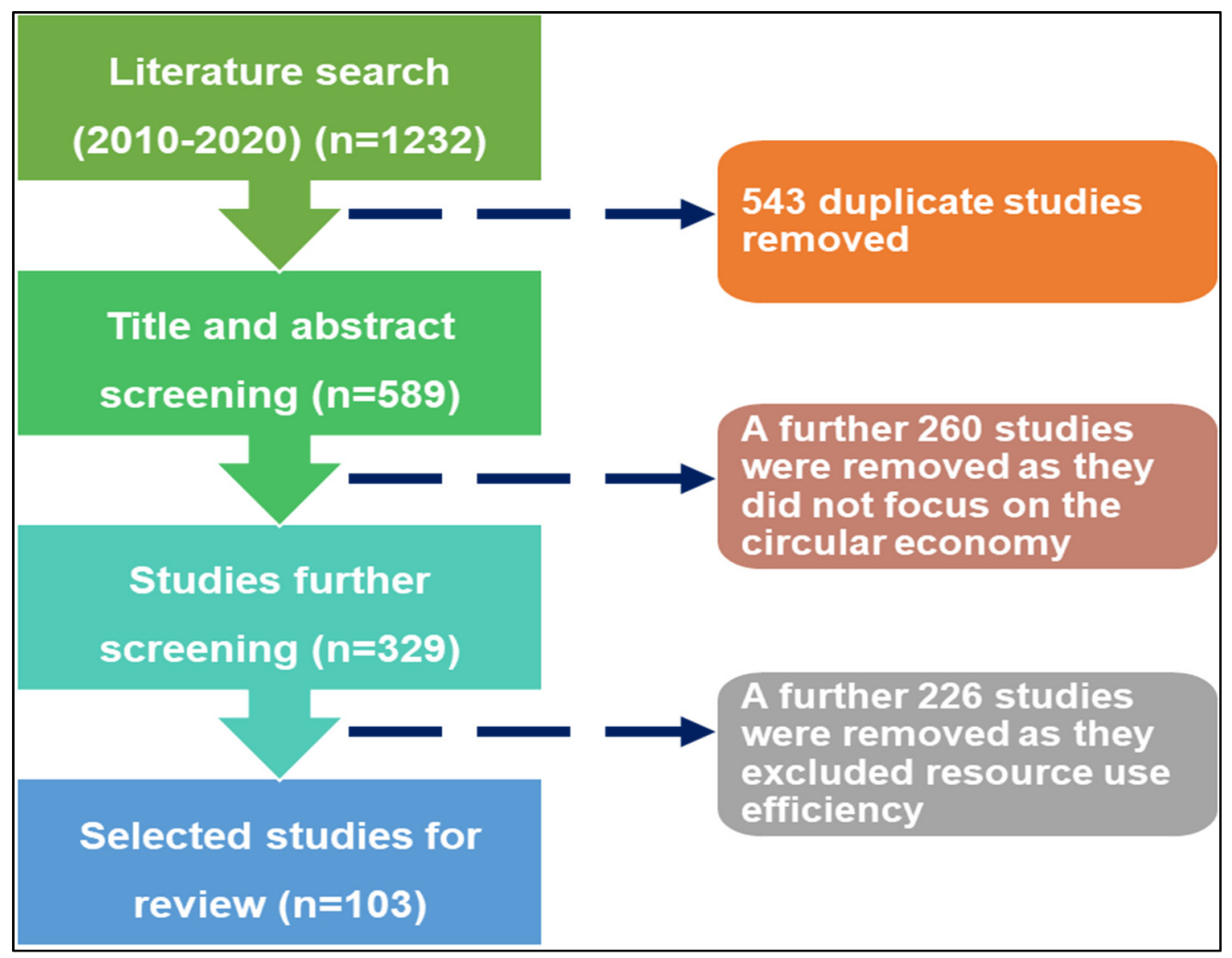

Figure 1. The PRISMA flow chart showing the literature search process used for this review.

The literature search plan (Figure 1) was designed to include three different searching strategies that include: (a) grey literature databases, (b) customised search engines, and (c) targeted websites. This strategy was necessary for reducing the risk of omitting relevant literature and other sources. The literature search considered literature that included those without abstracts, summaries, and executive summaries from where the literature was screened. This was necessary as there is other literature without abstracts. Data extraction considered the organisation, year of publication (2010 to 2020), the intended audience, and the document's objectives.

The initial search across databases generated 1232 potential studies. These studies were further refined using the inclusion and exclusion criteria by screening titles and abstracts and eliminating duplicate studies (Figure 1). The literature search was limited to peer-reviewed articles published in English between the years 2010-2020. After the application of the screening process was complete, 103 studies were identified to be relevant for this specific systematic review.

\subsection{Development of a Transitional Framework towards the Circular Economy}

The literature review facilitated the identification of the successes and bottlenecks associated with transitioning towards a circular economy. Identified challenges encountered in transitioning to a circular economy include changing the norm and adopting novel business models, focused integrated and cross-sectoral policy frameworks and standards, adequate financial investment, technological innovation, behavioural change in waste management, and human capacity development administrative capacity, among others. The comprehension of these pertinent issues enabled the development of a transitional conceptual framework formulated as a guiding strategic policy pathway towards achieving the circular economy. The framework integrates transformative approaches that include the circular economy itself, nexus planning, scenario planning, and sustainable agriculture systems as pathways towards the 2030 global agenda on sustainable development. 


\section{Results and Discussion}

\subsection{Circular Economy Research Progression over the Years (2010-2020)}

Figure 2 shows the countries that dominate circular economy research and implementation. Germany and China were the leading countries with over 11 circular economy-related research, followed by Australia, the United States of America, the United Kingdom, and Italy, which have between six and 10 studies. South Africa, Mexico, Canada, Spain, and Finland have one to five circular economy-related studies. Research on the circular economy in Africa remains minimal, with only South Africa having done more. South America and South-East Asia did not show any research related to the circular economy.

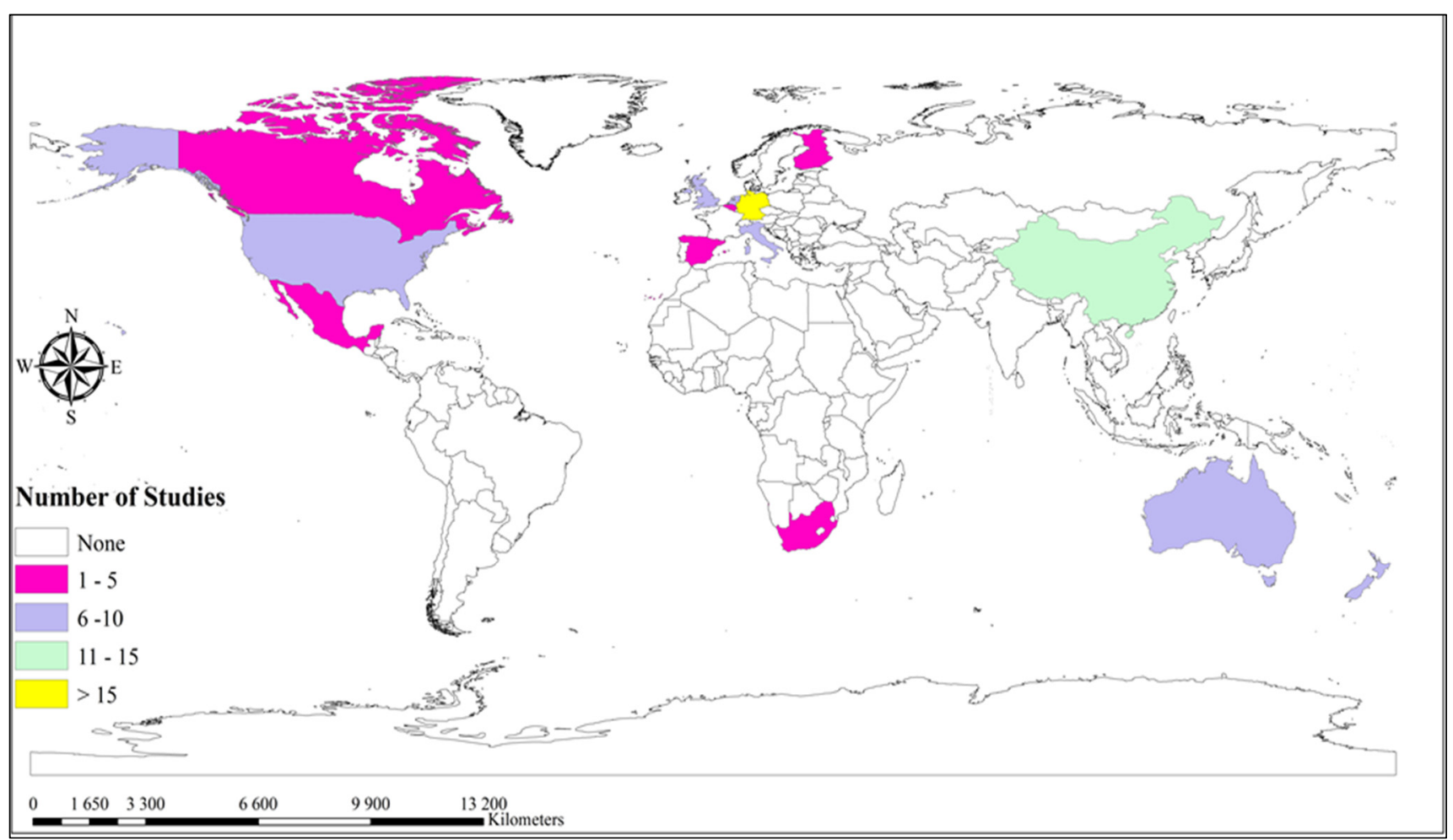

Figure 2. Countries where research on circular economy has gained popularity between 2010 and 2020.

The global distribution of circular economy research is still a long way to go besides the fact that it is a concept envisaged to drive economies towards sustainable development, reduce waste and global warming, and meet the targets of the Paris Agreement.

Figure 2 demonstrates that more needs to be done in adopting transformative models that inform the circular economy. Current linear models have reached their limitations and there is now an urgent need for a transformational change from the norm towards circular and cross-sectoral planning $[2,67,68]$. The limited uptake of the circular economy at the global scale is a potential risk to achieving the SDGs by 2030 and could derail the progress being made in enhancing water, energy, and food security. Even those countries that have made some effort in driving the circular economy, the pace has been low $[2,69]$. The absence of relevant policies compounds the challenges of the circular economy's slow uptake to drive the model's implementation process $[70,71]$.

\subsection{Circular Economy Research by Sector}

The bar graph in Figure 3 illustrates the various research contexts or circular economy research by sector. The energy sector has the most circular economy-related research, followed by water, waste, and agriculture. Interestingly, the concept is also gaining prominence in other sectors such as the food systems, mining, hospitality, and construction industries, as evidenced by previous studies [10,19]. 


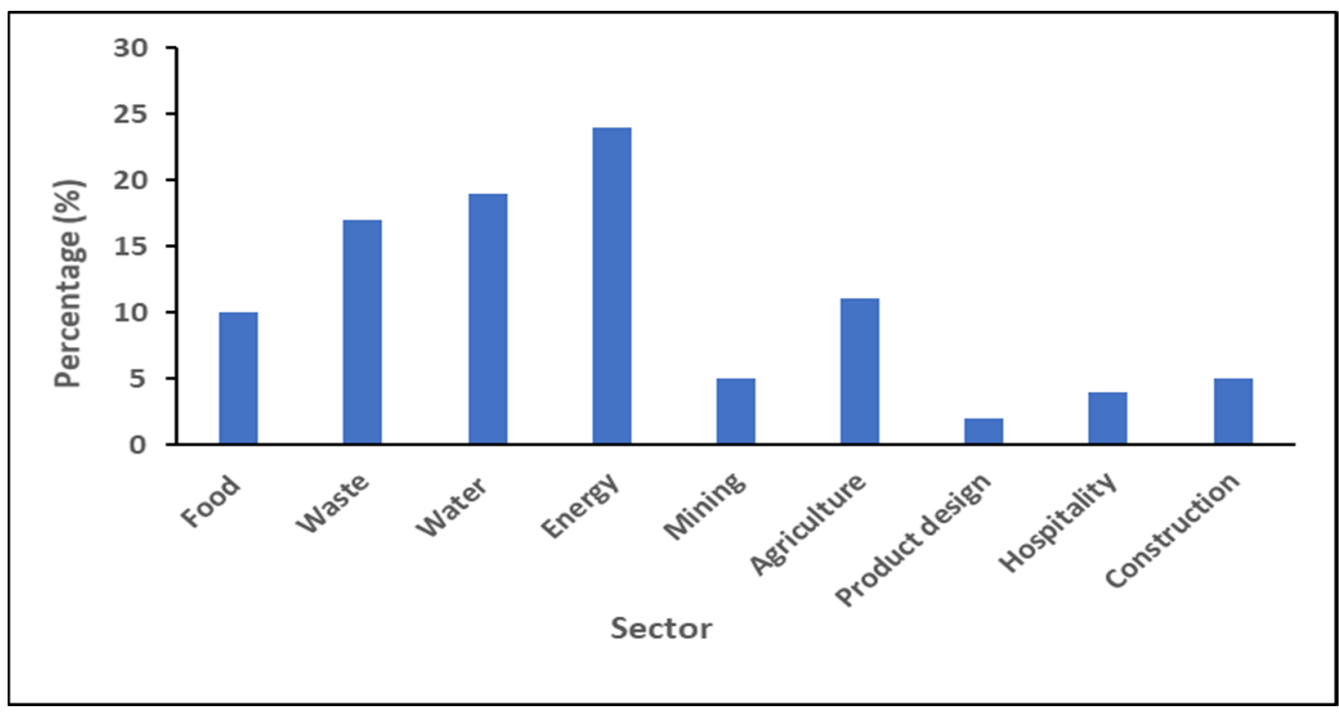

Figure 3. Main circular economy research by sector between 2010 and 2020.

The Fourth Industrial Revolution (4IR) brings some advanced technologies with the potential to accelerate the implementation of circular economy practices, which can promote the transition to a green economy and sustainable development [72]. Some of the innovations include communication networks based on the Internet of Things (IoT), Internet of Services (IoS), cloud manufacturing and computing, and cyber-physical systems [73,74]. The IoT is a digital transformation that is facilitating the storage, processing, and access of big data generated by various means and systems [75,76]. It is, therefore, promoting a circular economy culture into novel business models by facilitating the application of operational analytical models that integrate and support sustainable supply chains $[77,78]$. Thus, the 4IR and the IoT accelerate smart productivity by enhancing product tracking and access in near real-time and promoting smart production systems [78]. This allows easy access to information on production chains and tracking environmental impacts while improving resource use efficiency $[77,78]$. Furthermore, the IoT has become critical for informing strategic policy formulations that drive the circular economy [79]. As the IoT embraces all sectors, it is envisaged to accelerate the adoption of the circular economy by all sectors.

\subsection{Circular Economy Research Progression (2010-2020)}

The line graph shown in Figure 4 illustrates the progression of circular economy research between 2010 and 2020. Research on the circular economy was generally static between 2010 and 2016, with an average of about five publications per year. However, interest in the concept has since increased between 2018 and 2020, as indicated by the steep trend in research outputs related to the circular economy. The recent interest in the circular economy could be motivated by the global drive towards waste minimisation in an attempt to reduce resource insecurity, worsening pollution, and global warming [50]. The sudden increase in circular economy research from 2016 to date is also motivated by the amplified interest from policy and decision-makers towards adopting evidence-based research that advances the SDGs [62,79]. 


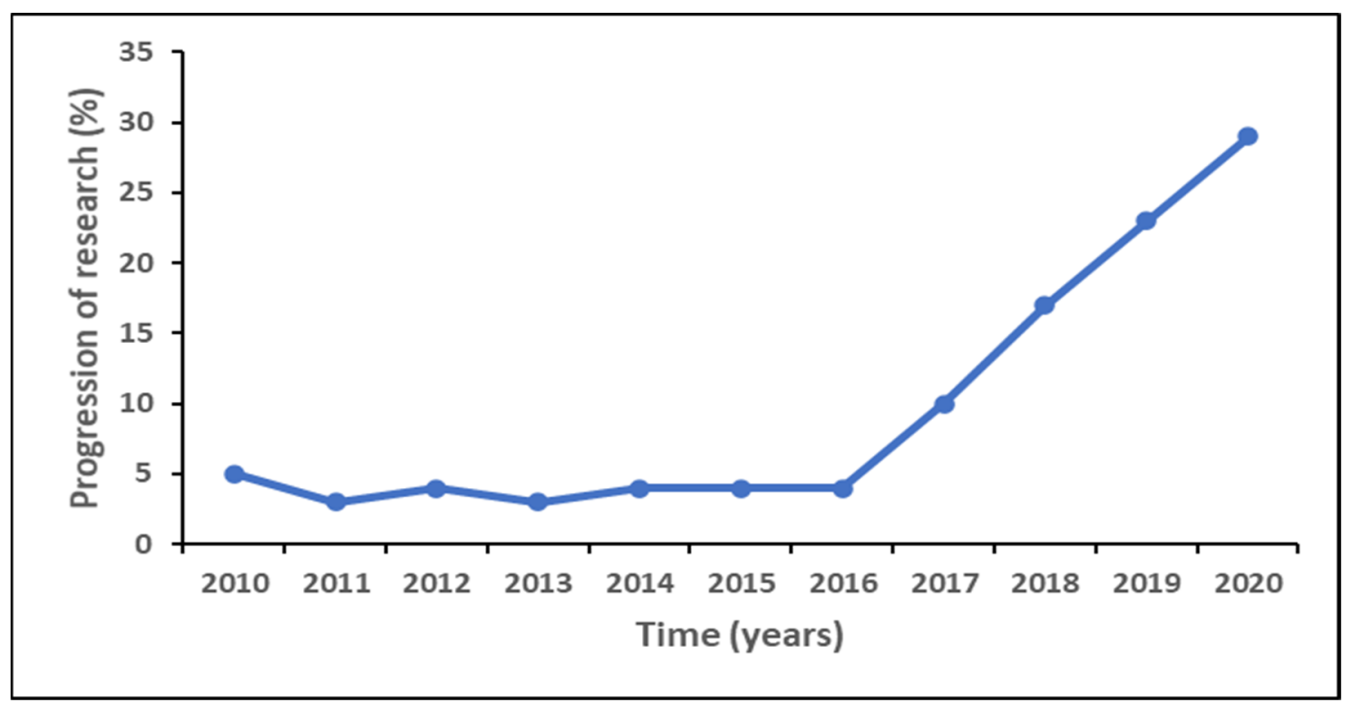

Figure 4. Circular economy research progression (2010-2020).

\subsection{Circular Economy Trends in the Context of Water and Energy}

The challenges associated with resource insecurity, increasing inequality and poverty, environmental degradation, and climate change resulted in the formulation of the SDGs to achieve sustainability by 2030 [29]. These challenges and the SDGs' ultimate formulation have increased interest in circular economy research as applied to the energy and water sectors (Figure 3). Water and energy have dedicated goals-6 (ensure availability and sustainable management of water and sanitation for all), and 7 (ensure access to affordable, reliable, sustainable, and modern energy). The attainment of these two intricately connected goals depends on contributing to and benefiting from the achievement of other SDGs, particularly in the context of the circular economy-related SDG, which is Goal 12 (ensure sustainable consumption and production patterns) [20]. This is an indicator of the interdependences across the SDGs, highlighting the need for greater cooperation amongst sectors, and is the core of sustainable development [1]. In most countries, water and energy can be instrumental in achieving sustainability. They are either scarce, shared, or abundant resources that can positively contribute to environmental, social, and economic sustainability [80].

Therefore, adopting the circular economy principles in water and energy is fundamental in achieving the SDG agenda, driven by sanitation, renewable and clean energy, and water reuse. However, limited progress in changing existing legal frameworks has been a drawback in understanding the resources' interlinkages. There is still a need for guiding policies to direct the transition to the circular economy [9,55]. This is because existing legal frameworks were developed in linear production and consumption patterns [55]. Meanwhile, the two sectors can still adopt innovative technologies and practices and move towards the circular economy. However, it is important to note that transitioning to a circular economy is driven by both external and internal factors, which stakeholders need to anticipate, respond to, and influence to ensure clear progress towards a circular economy and sustainable development [81]. The transition from linear to circular requires a shift from conventional models designed around linear production and consumption patterns to models that support the circular economy [55]. There are critical intersections where water and energy converge throughout the transition to a circular economy, and opportunities arise to facilitate the transition [82]. These intersections serve as points of analysis and action, where stakeholders can get an insight into and create partnerships for informed transitioning to the circular economy.

Energy consumption for water use is greatest at the household level as it is used for heating and other domestic uses $[83,84]$. Currently, water networks and treatment plants consume an average of between $10 \%$ and $15 \%$ of national power production globally [85]. 
Untreated sewage also contributes to GHG emissions. Thus, strategies related to energy and carbon should revolve around reducing costs for customers and minimising the impact on the environment. The energy sector should minimise consumption of non-renewable energy and make a positive contribution to zero-carbon cities [86].

\subsection{Challenges and Opportunities in Achieving a Circular Economy in the Water, Food, and Energy Sectors}

The insecurity of water, food, and energy resources is worsening in many regions of the world, particularly in urban areas of developing countries where households have resorted to using groundwater and biomass for domestic purposes [80,87]. However, the spatial extent of groundwater and its availability are unknown [88,89]. At the same time, the depletion rate of the forest is alarming [89], a scenario that has brought uncertainty in the supply of resources. As a result, many urban areas are rapidly running out of options, and now recognise the value of high-grade urban water treatment and the use of renewable sources of energy as cheaper and environmentally friendly alternatives $[45,90,91]$. This has become a reality worldwide, appearing more pronounced in water-scarce regions. In southern Africa, for example, there are urban areas that rely entirely on groundwater for their water supply [88]. Resource reuse, particularly recycling wastewater, reduces the environmental concerns of ever-increasing nutrient discharges in coastal waters [50]. The elimination of effluent discharges through treated wastewater application within compatible uses reduces the need for expensive nutrient removal treatment processes [50]. Wastewater treated to acceptable quality is useful for replenishing water supplies and reducing the demand/supply gap [50]. However, wastewater recycling and reuse in agricultural systems has faced criticism, as there are concerns that it could pose significant human and environmental health risks [92,93]. The risks include nutrient and sodium concentrations in croplands, as well as the presence of heavy metals and other contaminants like human and animal pathogens, pharmaceuticals, and endocrine disruptors in the environment when wastewater is used for irrigation [50,93].

As the world population is projected to reach 9 billion people by 2050, the demand for resources is also expected to increase [94]. Production systems are estimated to increase threefold than the current consumption, using about 140 billion tons of minerals, fossil fuels, and biomass per annum [95]. Global food production will have to increase by $50 \%$ during the same period [96]. To reduce waste during this period of unprecedented demand and achieve sustainability, there is a need to use resources efficiently. Otherwise, the challenges will be unsurmountable. Projections indicate that by 2030, food losses and wastes will reach about 2.1 billion tons, representing a third of food intended for human consumption [97] due to current linear economic models. This is happening while about 900 million people are food insecure worldwide [97]. These developments call for a transformational change in food systems through technological developments such as the IoT that enhance the circular economy initiatives, resource use efficiency, and food security [98]. The 4IR and the adoption of its smart technologies is the first step in transitioning towards sustainable food systems [99], and the provision of healthy and nutritious diets for all and at all times without compromising the environment [100]. This is the main reason why food systems are at the heart of Sustainable Development Goals (SDGs) and are linked to at least 12 of the 17 goals $[29,101]$.

On the other hand, most electronic goods are disposed of in the environment. In 2016 there were about 45 million tons of electronic waste worldwide [102]. Nearly nine million tons of plastic waste annually end up in the ocean, as only $~ 20 \%$ is recycled [103]. These challenges require an urgent shift from current linear models to circular ones that optimise the use of waste as a resource and extend the lifespan of products, parts, and components while reducing water and energy consumption. Although the circular economy concept has gained prominence in recent years, many challenges still need to be addressed to operationalise the concept [104]. As already alluded to, the pathway towards the circular economy has controlled intersections where water, energy, or materials meet to provide opportunities that facilitate the transition [82]. These intersections are an opportunity to 
analyse and opt for the best and informed options, guided by transformative approaches that lead to the circular economy. These other transformative approaches include nexus planning, sustainable agricultural systems, and scenario planning.

\subsection{Strengths and Limitations of the Evidence}

The authors adopted a systematic review approach and tried to be exhaustive during the selection process of papers to be reviewed. This work's main contribution is to provide a 'bird's eye view' on research and trends related to the circular economy. However, there are still gaps in the literature regarding sustainability and green economy-related aspects and their association with circular economy indicators. The study does not include conference papers; given the novelty of the circular economy concept, these could provide important insights regarding what areas of interest are emerging. Furthermore, a ten-year time scale was applied for this review; this could be a limitation as any articles before this time scale was not part of the search process. Lastly, three search engines were utilised to find relevant literature on the circular economy. This included Google Scholar, EBSCOhost, and Scopus. There are many additional search engines and certain articles that could have been missed during the selection process. Despite these pros and cons, it remains critical to provide policy and decision-making with some guidelines to achieve the circular economy. This has been the missing link between the circular economy and its adoption, particularly in the global South [105].

The results from the literature review facilitated the development of a conceptual framework to guide strategic policy formulations that drive economies towards a more sustainable circular economy. Transitioning towards circularity is urgent, given the speed at which the natural resource base is degrading and depleting [2]. The coming section describes the themes of the proposed circular economy conceptual framework.

\section{Pathways to Achieve the Circular Economy}

Importantly, adopting the circular economy is envisaged to enhance resource-use efficiency in the advent of resource depletion, degradation, and insecurity, integrating other concepts such as cleaner production and industrial ecology that also cover the food sector. The identified factors formed the basis for developing the conceptual framework. The framework is built in a way that allows the integration of related sectors in a nonlinear format. It includes industry, production chains, eco-industrial parks, and built and ecological infrastructures to support resource optimisation from private and public sectors [81]. Identified action levels that form the foundation of a circular economy include (a) seeking a much higher resource-use efficiency through the three Rs of Cleaner Production (reduce consumption of resources and emission of pollutants and waste, reuse resources, and recycle by-products), (b) the reuse and recycling of resources to facilitate the full circulation of resources in the local production system, and (c) the integration of different production and consumption to facilitate resource circulation among industries and urban systems $[104,105]$. The three levels (incorporated into the conceptual framework) require the development of smart technologies to facilitate the collection, storage, processing, and distribution of by-products, as indicated in Figure 5. Efforts to achieve all three levels include the development of resource recovery and cleaner production facilities. This requires investments in new ventures that would translate into job creation, opening opportunities for domestic and foreign enterprises, and economic development. An identified interactive approach to drive economies towards a new paradigm of the circular economy is the adoption and use of the theory of change to inform the operationalisation of a circularity-driven economy [3]. 


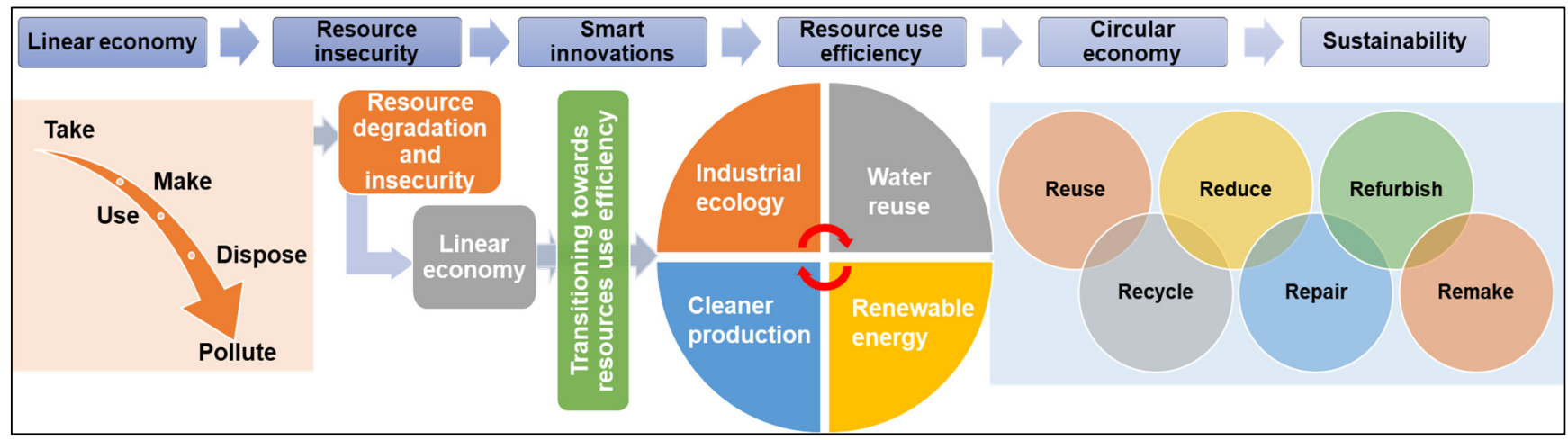

Figure 5. A conceptual framework indicating the processes in transitioning towards resource use efficiency and ultimately the circular economy.

Six identified thematic areas facilitate the transition to a circular economy; these include (i) linear economic models that increase waste, (ii) resource insecurity and degradation, (iii) development of smart technologies that guide the transition to the circular economy, (iv) resource use efficiency, (v) novel circular models that reduce waste and promote cleaner production, and (vi) sustainable development (Figure 5). Transitioning to cleaner and renewable energy sources is one of the most critical environmental issues that humankind needs to address urgently. The planet has been warming up since the 1st Industrial Revolution with the consequences of rising sea levels, increasing natural disasters, heat waves, and other extreme weather events [29]. Studies have shown a close link between human activity and global warming, and the main reason for this is the over-consumption of fossil fuels, which has led to an increase in GHG emissions in the atmosphere [106,107]. The circular economy is envisaged to transition to cleaner energy systems and water reuse. The two processes that lead to a circular economy include (a) producing differently, and (b) consuming differently [9]. This requires a shift in production systems, transitioning from carbon-based energy (oil, gas, coal) to clean energy (solar, wind, and hydro). The aim is to achieve efficiency in energy use, which is the difference between the energy used and the total energy consumed (often higher due to losses) and interpreted as energy productivity [108]. The circular economy is a pathway that guides the development of innovative and efficient energy solutions (Figure 5).

As water is at the centre of sustainable development, it is critical for socio-economic development, energy, and food production. It is fundamental for ensuring healthy ecosystems and their services to humankind and the rest of the environment [50]. Water and sanitation are essential for minimising the burden of disease outbreaks and improving human health and economic productivity. Therefore, water reuse closes that loop between water supply and sanitation, and besides, it provides an alternative source of water [109]. In a circular economy, wastewater is treated to the right quality. It can be used to replenish degrading water sources, ensure sufficient supplies, and reduce the demand and availability gap (Figure 5).

\section{Policy Implications}

An important component also required in transitioning economies to a circular economy is the political will which is reflected through appropriate policy frameworks. Circular economy-related policies form an integral part of the pathways needed in transitioning to a circular economy as they are a catalyst in transformational change [9,55]. This is particularly relevant because the current linear models driving industrial production are rooted in a practice where inputs are extracted, combined, processed, consumed, and discarded. There is an urgent need to formulate new policy frameworks that promote the new norm of resource "reduce, reuse, and recycle" from the current principle of the "take-make-dispose" system. Current challenges of resource degradation, depletion, and 
insecurity have highlighted the need to formulate policies that stimulate circularity in resource extraction, production, and consumption [2,3].

The need to formulate policies that promote the circular economy is urgent as the current global economy is only 9\% circular [55], an indication of the linearity of the global economy. This calls for more robust research that focuses on the policy mix in integrated and cross-sectoral pathways towards the circular economy and stimulates resource efficiency, stressing primary and supplementary policy frameworks such as material taxes, extended producer responsibility, and technical requirements [55]. The integration of circular economy-related policies is based on the fact that no single policy can advance the cross-sectoral interlinkages between industries and policy domains needed for circular economy transition.

\section{Conclusions}

This study assessed the progress made towards achieving the circular economy for the period 2010 to 2020. The focus was on the potential of improved water energy, and food resource use efficiencies through adopting a circular economy. The review showed that the circular economy gained momentum between 2018 and 2020 as a viable and practical alternative to current linear economic models. However, much of this progression has been driven by the Global North. Research on the circular economy from the Global South, especially in Africa, is still in its infancy, with only South Africa making some real strides towards the model. This highlights that the Global South may still be lagging in transitioning towards sustainable natural resource management. Despite the circular economy being an integrated approach, this study showed a bias towards an energy focus. There is a need to establish stronger linkages to water and food, motivating its adoption by policymakers. However, the literature review results facilitated the development of a proposed conceptual framework to guide strategic policy formulations that lead to sustainable economies. Embedding the circular economy within a more polycentric approach such as the water-energy-food nexus might help counter this bias and potentially breed success as this integration represents fundamental opportunities for transitioning. As a transformative approach, the circular economy approach can provide pathways towards sustainable development in terms of integrating economic, social, and sustainable natural resource management outcomes. Thus, it is fundamental in achieving several interlinked SDGs.

Author Contributions: Conceptualization, D.N., T.M. and L.N.; methodology, L.N., S.L. (Shennelle Lottering) and T.M.; validation, S.L. (Stanley Liphadzi), C.T., S.M., A.T.M. and D.N.; formal analysis, S.L. (Shennelle Lottering), L.N. and T.M.; investigation, S.L. (Shennelle Lottering); resources, L.N. and S.L. (Shennelle Lottering); data curation, C.T.; writing-original draft preparation, S.L. (Shennelle Lottering), L.N. and T.M.; writing—review and editing, T.M., S.M., S.L. (Stanley Liphadzi) and A.T.M.; visualization, S.L. (Stanley Liphadzi), C.T., S.M. and D.N.; supervision, A.T.M.; project administration, D.N.; funding acquisition, L.N. All authors have read and agreed to the published version of the manuscript.

Funding: This research was funded by the Water Research Commission of South Africa (WRC), and The APC was funded by Water Research Commission through the Research and Development (R\&D) Branch.

Institutional Review Board Statement: Not applicable.

Informed Consent Statement: Not applicable.

Acknowledgments: The authors would like to acknowledge the support received from the WEF Nexus Lighthouse of the Water Research Commission (WRC) through the Research and Development Branch as well as the Sustainable and Healthy Food Systems (SHEFS) Programme funded by the Wellcome Trust (Grant number-205200/Z/16/Z); A.T.M. and T.M. are supported by the SHEFS Programme.

Conflicts of Interest: The authors declare no conflict of interest. 


\section{References}

1. Mensah, J.; Ricart Casadevall, S. Sustainable development: Meaning, history, principles, pillars, and implications for human action: Literature review. Cogent. Soc. Sci. 2019, 5, 1653531. [CrossRef]

2. Nhamo, L.; Ndlela, B. Nexus planning as a pathway towards sustainable environmental and human health post COVID-19. Environ. Res. 2020, 110376, 7. [CrossRef]

3. Naidoo, D.; Nhamo, L.; Mpandeli, S.; Sobratee, N.; Senzanje, A.; Liphadzi, S.; Slotow, R.; Jacobson, M.; Modi, A.; Mabhaudhi, T. Operationalising the water-energy-food nexus through the theory of change. Renew. Sustain. Energy Rev. 2021, 149, 10. [CrossRef]

4. Winans, K.; Kendall, A.; Deng, H. The history and current applications of the circular economy concept. Renew. Sustain. Energy Rev. 2017, 68, 825-833. [CrossRef]

5. Smith, M. Sustainable Development Goals: Genuine global change requires genuine measures of efficacy. J. Maps 2020. [CrossRef]

6. Mabhaudhi, T.; Nhamo, L.; Chibarabada, T.P.; Mabaya, G.; Mpandeli, S.; Liphadzi, S.; Senzanje, A.; Naidoo, D.; Modi, A.T.; Chivenge, P.P. Assessing Progress towards Sustainable Development Goals through Nexus Planning. Water 2021, $13,1321$. [CrossRef]

7. Hofstetter, J.S.; De Marchi, V.; Sarkis, J.; Govindan, K.; Klassen, R.; Ometto, A.R.; Spraul, K.S.; Bocken, N.; Ashton, W.S.; Sharma, S. From Sustainable Global Value Chains to Circular Economy-Different Silos, Different Perspectives, but Many Opportunities to Build Bridges. Circ. Econ. Sustain. 2021, 1-27. [CrossRef]

8. Kalmykova, Y.; Sadagopan, M.; Rosado, L. Circular economy-From review of theories and practices to development of implementation tools. Resour. Conserv. Recycl. 2018, 135, 190-201. [CrossRef]

9. Milios, L. Advancing to a Circular Economy: Three essential ingredients for a comprehensive policy mix. Sustain. Sci. 2018, 13, 861-878. [CrossRef]

10. Oliveira, M.; Miguel, M.; van Langen, S.K.; Ncube, A.; Zucaro, A.; Fiorentino, G.; Passaro, R.; Santagata, R.; Coleman, N.; Lowe, B.H. Circular Economy and the Transition to a Sustainable Society: Integrated Assessment Methods for a New Paradigm. Circ. Econ. Sustain. 2021, 1-15. [CrossRef]

11. Njoroge, P.; Ambole, A.; Githira, D.; Outa, G. Steering energy transitions through landscape governance: Case of Mathare informal settlement, Nairobi, Kenya. Land 2020, 9, 206. [CrossRef]

12. Camacho-Otero, J.; Boks, C.; Pettersen, I.N. Consumption in the circular economy: A literature review. Sustainability 2018, 10, 2758. [CrossRef]

13. Smol, M.; Adam, C.; Preisner, M. Circular economy model framework in the European water and wastewater sector. J. Mater. Cycles Waste Manag. 2020, 1-16. [CrossRef]

14. Klein, N.; Ramos, T.B.; Deutz, P. Circular economy practices and strategies in public sector organizations: An integrative review. Sustainability 2020, 12, 4181. [CrossRef]

15. Garcés-Ayerbe, C.; Rivera-Torres, P.; Suárez-Perales, I.; Leyva-De La Hiz, D.I. Is it possible to change from a linear to a circular economy? An overview of opportunities and barriers for European small and medium-sized enterprise companies. Int. J. Environ. Res. Public Health 2019, 16, 851. [CrossRef] [PubMed]

16. Katz-Gerro, T.; López Sintas, J. Mapping circular economy activities in the European Union: Patterns of implementation and their correlates in small and medium-sized enterprises. Bus. Strategy Environ. 2019, 28, 485-496. [CrossRef]

17. Bretschger, L.; Pittel, K. Twenty Key Challenges in Environmental and Resource Economics. Environ. Resour. Econ. 2020, 77, 725-750. [CrossRef]

18. Mpandeli, S.; Naidoo, D.; Mabhaudhi, T.; Nhemachena, C.; Nhamo, L.; Liphadzi, S.; Hlahla, S.; Modi, A. Climate change adaptation through the water-energy-food nexus in southern Africa. Int. J. Environ. Res. Public Health 2018, 15, 2306. [CrossRef]

19. Kyriakopoulos, G.L.; Kapsalis, V.C.; Aravossis, K.G.; Zamparas, M.; Mitsikas, A. Evaluating circular economy under a multiparametric approach: A technological review. Sustainability 2019, 11, 6139. [CrossRef]

20. Hysa, E.; Kruja, A.; Rehman, N.U.; Laurenti, R. Circular economy innovation and environmental sustainability impact on economic growth: An integrated model for sustainable development. Sustainability 2020, 12, 4831. [CrossRef]

21. Cucciniello, R.; Cespi, D. Recycling within the chemical industry: The circular economy era. Recycling 2018, 3, 22. [CrossRef]

22. Muscio, A.; Sisto, R. Are agri-food systems really switching to a circular economy model? Implications for European research and innovation policy. Sustainability 2020, 12, 5554. [CrossRef]

23. Morseletto, P. Targets for a circular economy. Resour. Conserv. Recycl. 2020, 153, 104553. [CrossRef]

24. Stahel, W.R. The Business Angle of a Circular Economy-Higher Competitiveness, Higher Resource Security and Material Efficiency; The Product-Life Institute: Geneva, Switzerland, 2013; p. 10.

25. Beccarello, M.; Di Foggia, G. Moving towards a circular economy: Economic impacts of higher material recycling targets. Mater Today Proc. 2018, 5, 531-543. [CrossRef]

26. Fogarassy, C.; Finger, D. Theoretical and practical approaches of circular economy for business models and technological solutions. Resources 2020, 9, 76. [CrossRef]

27. Mathews, J.A.; Tan, H. Circular economy: Lessons from China. Nat. News 2016, 531, 440. [CrossRef] [PubMed]

28. Domenech, T.; Bahn-Walkowiak, B. Transition towards a resource efficient circular economy in Europe: Policy lessons from the EU and the member states. Ecol. Econ. 2019, 155, 7-19. [CrossRef]

29. UNGA. Transforming Our World: The 2030 Agenda for Sustainable Development; United Nations General Assembly: New York, NY, USA, 2015; p. 35. 
30. Lehmann, S. Implementing the Urban Nexus approach for improved resource-efficiency of developing cities in Southeast-Asia. City Cult. Soc. 2018, 13, 46-56. [CrossRef]

31. Al-Saidi, M.; Das, P.; Saadaoui, I. Circular Economy in Basic Supply: Framing the Approach for the Water and Food Sectors of the Gulf Cooperation Council Countries. Sustain. Prod. Consum. 2021, 27, 1273-1285. [CrossRef]

32. Godoy-Faúndez, A.; Rivera, D.; Aitken, D.; Herrera, M.; El Youssfi, L. Circular Economy in a Water-Energy-Food Security Nexus Associate to an SDGs Framework: Understanding Complexities. In An Introduction to Circular Econom; Springer: Singapore, 2021; pp. 219-239.

33. EC. Circular Economy Action Plan: For a Cleaner and More Competitive Europe; European Commission (EC): Brussels, Belgium, 2020; p. 28.

34. Ibrahim, A.-J.; Shirazi, N.S. Energy-Water-Environment Nexus and the Transition Towards a Circular Economy: The Case of Qatar. Circ. Econ. Sustain. 2021, 1-16. [CrossRef]

35. Koppelmäki, K.; Helenius, J.; Schulte, R.P. Nested circularity in food systems: A Nordic case study on connecting biomass, nutrient and energy flows from field scale to continent. Resour. Conserv. Recycl. 2021, 164, 105218. [CrossRef]

36. Van der Wiel, B.Z.; Weijma, J.; van Middelaar, C.E.; Kleinke, M.; Buisman, C.J.N.; Wichern, F. Restoring nutrient circularity: A review of nutrient stock and flow analyses of local agro-food-waste systems. Resour. Conserv. Recycl. X 2019, 3, 100014. [CrossRef]

37. Papangelou, A.; Achten, W.M.; Mathijs, E. Phosphorus and energy flows through the food system of Brussels Capital Region. Resour. Conserv. Recycl. 2020, 156, 104687. [CrossRef]

38. Mrówczyńska-Kamińska, A.; Bajan, B.; Pawłowski, K.P.; Genstwa, N.; Zmyślona, J. Greenhouse gas emissions intensity of food production systems and its determinants. PLoS ONE 2021, 16, e0250995. [CrossRef] [PubMed]

39. Wang, Z.B.; Zhang, J.Z.; Zhang, L.F. Reducing the carbon footprint per unit of economic benefit is a new method to accomplish low-carbon agriculture. A case study: Adjustment of the planting structure in Zhangbei County, China. J. Sci. Food Agric. 2019, 99, 4889-4897. [CrossRef] [PubMed]

40. Manowska, A.; Nowrot, A. The importance of heat emission caused by global energy production in terms of climate impact. Energies 2019, 12, 3069. [CrossRef]

41. Kho, E.T.; Tan, T.H.; Lovell, E.; Wong, R.J.; Scott, J.; Amal, R. A review on photo-thermal catalytic conversion of carbon dioxide. Green Energy Environ. 2017, 2, 204-217. [CrossRef]

42. Jury, W.A.; Vaux, H. The role of science in solving the world's emerging water problems. Proc. Natl. Acad. Sci. USA 2005, 102, 15715-15720. [CrossRef]

43. Misra, A.K. Climate change and challenges of water and food security. Int. J. Sustain. Built Environ. 2014, 3, 153-165. [CrossRef]

44. Nhamo, L.; Mabhaudhi, T.; Mpandeli, S.; Dickens, C.; Nhemachena, C.; Senzanje, A.; Naidoo, D.; Liphadzi, S.; Modi, A.T. An integrative analytical model for the water-energy-food nexus: South Africa case study. Environ. Sci. Policy 2020, 109, 15-24. [CrossRef]

45. Nhamo, L.; Rwizi, L.; Mpandeli, S.; Botai, J.; Magidi, J.; Tazvinga, H.; Sobratee, N.; Liphadzi, S.; Naidoo, D.; Modi, A.; et al. Urban nexus and transformative pathways towards a resilient Gauteng City-Region, South Africa. Cities 2021, 116. [CrossRef]

46. D'Amato, D. Sustainability Narratives as Transformative Solution Pathways: Zooming in on the Circular Economy. Circ. Econ. Sustain. 2021, 1-12. [CrossRef]

47. Lüdeke-Freund, F.; Gold, S.; Bocken, N.M. A review and typology of circular economy business model patterns. J. Ind. Ecol. 2019, 23, 36-61. [CrossRef]

48. Nhemachena, C.; Nhamo, L.; Matchaya, G.; Nhemachena, C.R.; Muchara, B.; Karuaihe, S.T.; Mpandeli, S. Climate Change Impacts on Water and Agriculture Sectors in Southern Africa: Threats and Opportunities for Sustainable Development. Water 2020, 12, 2673. [CrossRef]

49. Nhamo, L.; Mpandeli, S.; Senzanje, A.; Liphadzi, S.; Naidoo, D.; Modi, A.T.; Mabhaudhi, T. Transitioning Toward Sustainable Development Through the Water-Energy-Food Nexus. In Sustaining Tomorrow via Innovative Engineering; Ting, D., Carriveau, R., Eds.; World Scientific: Singapore, 2021; pp. 311-332.

50. Voulvoulis, N. Water reuse from a circular economy perspective and potential risks from an unregulated approach. Curr. Opin. Environ. Sci. Health 2018, 2, 32-45. [CrossRef]

51. Tortajada, C. Contributions of recycled wastewater to clean water and sanitation Sustainable Development Goals. NPJ Clean Water 2020, 3, 1-6. [CrossRef]

52. Gilbert, N. One-third of our greenhouse gas emissions come from agriculture. Nature 2012, 31, 10-12. [CrossRef]

53. Abdel-Shafy, H.I.; Mansour, M.S. Solid waste issue: Sources, composition, disposal, recycling, and valorization. Egypt. J. Pet. 2018, 27, 1275-1290. [CrossRef]

54. Dieckmann, E.; Sheldrick, L.; Tennant, M.; Myers, R.; Cheeseman, C. Analysis of Barriers to Transitioning from a Linear to a Circular Economy for End of Life Materials: A Case Study for Waste Feathers. Sustainability 2020, 12, 1725. [CrossRef]

55. Hartley, K.; van Santen, R.; Kirchherr, J. Policies for transitioning towards a circular economy: Expectations from the European Union (EU). Resour. Conserv. Recycl. 2020, 155, 104634. [CrossRef]

56. McGrane, S.J. Impacts of urbanisation on hydrological and water quality dynamics, and urban water management: A review. Hydrol. Sci. J. 2016, 61, 2295-2311. [CrossRef]

57. Kookana, R.S.; Drechsel, P.; Jamwal, P.; Vanderzalm, J. Urbanisation and emerging economies: Issues and potential solutions for water and food security. Sci. Total Environ. 2020, 732, 139057. [CrossRef] 
58. Anwar, A.; Younis, M.; Ullah, I. Impact of urbanization and economic growth on $\mathrm{CO}_{2}$ emission: A case of far east Asian countries. Int. J. Environ. Res. Public Health 2020, 17, 2531. [CrossRef] [PubMed]

59. Sodiq, A.; Baloch, A.A.; Khan, S.A.; Sezer, N.; Mahmoud, S.; Jama, M.; Abdelaal, A. Towards modern sustainable cities: Review of sustainability principles and trends. J. Clean. Prod. 2019, 227, 972-1001. [CrossRef]

60. Ghisellini, P.; Cialani, C.; Ulgiati, S. A review on circular economy: The expected transition to a balanced interplay of environmental and economic systems. J. Clean. Prod. 2016, 114, 11-32. [CrossRef]

61. Ferronato, N.; Torretta, V. Waste mismanagement in developing countries: A review of global issues. Int. J. Environ. Res. Public Health 2019, 16, 1060. [CrossRef]

62. Abad-Segura, E.; González-Zamar, M.-D.; Belmonte-Ureña, L.J. Effects of Circular Economy Policies on the Environment and Sustainable Growth: Worldwide Research. Sustainability 2020, 12, 5792. [CrossRef]

63. Avilés-Palacios, C.; Rodríguez-Olalla, A. The Sustainability of Waste Management Models in Circular Economies. Sustainability 2021, 13, 7105. [CrossRef]

64. Padilla-Rivera, A.; Russo-Garrido, S.; Merveille, N. Addressing the Social Aspects of a Circular Economy: A Systematic Literature Review. Sustainability 2020, 12, 7912. [CrossRef]

65. Liberati, A.; Altman, D.G.; Tetzlaff, J.; Mulrow, C.; Gøtzsche, P.C.; Ioannidis, J.P.; Clarke, M.; Devereaux, P.J.; Kleijnen, J.; Moher, D. The PRISMA statement for reporting systematic reviews and meta-analyses of studies that evaluate health care interventions: Explanation and elaboration. J. Clin. Epidemiol. 2009, 62, e1-e34. [CrossRef] [PubMed]

66. Page, M.J.; Moher, D.; Bossuyt, P.M.; Boutron, I.; Hoffmann, T.C.; Mulrow, C.D.; Shamseer, L.; Tetzlaff, J.M.; Akl, E.A.; Brennan, S.E. PRISMA 2020 explanation and elaboration: Updated guidance and exemplars for reporting systematic reviews. BMJ 2021, 372. [CrossRef]

67. Jørgensen, S.; Pedersen, L.J.T. The circular rather than the linear economy. In Restart Sustainable Business Model Innovation; Shrivastava, P., Zsolnai, L., Eds.; Springer: Geneva, Switzerland, 2018; pp. 103-120.

68. Tura, N.; Hanski, J.; Ahola, T.; Ståhle, M.; Piiparinen, S.; Valkokari, P. Unlocking circular business: A framework of barriers and drivers. J. Clean. Prod. 2019, 212, 90-98. [CrossRef]

69. Ibn-Mohammed, T.; Mustapha, K.; Godsell, J.; Adamu, Z.; Babatunde, K.; Akintade, D.; Acquaye, A.; Fujii, H.; Ndiaye, M.; Yamoah, F. A critical review of the impacts of COVID-19 on the global economy and ecosystems and opportunities for circular economy strategies. Resour. Conserv. Recycl. 2020, 105169. [CrossRef]

70. D'Adamo, I. Adopting a circular economy: Current practices and future perspectives. Soc. Sci. 2019, 8, 328. [CrossRef]

71. Palm, J.; Bocken, N. Achieving the circular economy: Exploring the role of local governments, business and citizens in an urban context. Energies 2021, 14, 875. [CrossRef]

72. Hoosain, M.S.; Paul, B.S.; Ramakrishna, S. The impact of 4ir digital technologies and circular thinking on the united nations sustainable development goals. Sustainability 2020, 12, 143. [CrossRef]

73. Alhawari, O.; Awan, U.; Bhutta, M.K.S.; Ülkü, M.A. Insights from circular economy literature: A review of extant definitions and unravelling paths to future research. Sustainability 2021, 13, 859. [CrossRef]

74. Nobre, G.C.; Elaine, T. Scientific literature analysis on big data and internet of things applications on circular economy: A bibliometric study. Scientometrics 2017, 111, 463-492. [CrossRef]

75. Nagy, J.; Oláh, J.; Erdei, E.; Máté, D.; Popp, J. The role and impact of Industry 4.0 and the internet of things on the business strategy of the value chain-the case of Hungary. Sustainability 2018, 10, 3491. [CrossRef]

76. Hossein Motlagh, N.; Mohammadrezaei, M.; Hunt, J.; Zakeri, B. Internet of Things (IoT) and the energy sector. Energies 2020, 13, 494. [CrossRef]

77. Mastos, T.D.; Nizamis, A.; Terzi, S.; Gkortzis, D.; Papadopoulos, A.; Tsagkalidis, N.; Ioannidis, D.; Votis, K.; Tzovaras, D. Introducing an application of an industry 4.0 solution for circular supply chain management. J. Clean. Prod. 2021, 300, 126886. [CrossRef]

78. Alonso-Muñoz, S.; González-Sánchez, R.; Siligardi, C.; García-Muiña, F.E. New Circular Networks in Resilient Supply Chains: An External Capital Perspective. Sustainability 2021, 13, 6130. [CrossRef]

79. Ingemarsdotter, E.; Jamsin, E.; Balkenende, R. Opportunities and challenges in IoT-enabled circular business model implementation-A case study. Resour. Conserv. Recycl. 2020, 162, 105047. [CrossRef]

80. Nhamo, L.; Ndlela, B.; Nhemachena, C.; Mabhaudhi, T.; Mpandeli, S.; Matchaya, G. The water-energy-food nexus: Climate risks and opportunities in southern Africa. Water 2018, 10, 567. [CrossRef]

81. Salvioni, D.M.; Almici, A. Transitioning toward a circular economy: The impact of stakeholder engagement on sustainability culture. Sustainability 2020, 12, 8641. [CrossRef]

82. Bianchini, A.; Rossi, J.; Pellegrini, M. Overcoming the Main Barriers of Circular Economy Implementation through a New Visualization Tool for Circular Business Models. Sustainability 2019, 11, 6614. [CrossRef]

83. Sangoi, J.M.; Ghisi, E. Energy efficiency of water heating systems in single-family dwellings in Brazil. Water 2019, 11, 1068. [CrossRef]

84. Hohne, P.; Kusakana, K.; Numbi, B. A review of water heating technologies: An application to the South African context. Energy Rep. 2019, 5, 1-19. [CrossRef]

85. IWA. Water Utility Pathways in a Circular Economy; International Water Association (IWA): London, UK, 2016 ; p. 20. 
86. Majid, A.; Cardenes, I.; Zorn, C.; Russell, T.; Colquhoun, K.; Bañares-Alcantara, R.; Hall, J.W. An analysis of electricity consumption patterns in the water and wastewater sectors in South East England, UK. Water 2020, 12, 225. [CrossRef]

87. Andrews-Speed, P.; Bleischwitz, R.; Boersma, T.; Johnson, C.; Kemp, G.; VanDeveer, S.D. Want, Waste or War?: The Global Resource Nexus and the Struggle for Land, Energy, Food, Water and Minerals; Routledge: New York, NY, USA, 2015.

88. Nhamo, L.; Ebrahim, G.Y.; Mabhaudhi, T.; Mpandeli, S.; Magombeyi, M.; Chitakira, M.; Magidi, J.; Sibanda, M. An assessment of groundwater use in irrigated agriculture using multi-spectral remote sensing. Phys. Chem. EarthParts A/B/C 2020, 115, 102810. [CrossRef]

89. D'Annunzio, R.; Sandker, M.; Finegold, Y.; Min, Z. Projecting global forest area towards 2030. For. Ecol. Manag. 2015, 352, 124-133. [CrossRef]

90. Owusu, P.A.; Asumadu-Sarkodie, S. A review of renewable energy sources, sustainability issues and climate change mitigation. Cogent Eng. 2016, 3, 1167990. [CrossRef]

91. Leigh, N.G.; Lee, H. Sustainable and resilient urban water systems: The role of decentralization and planning. Sustainability 2019, 11, 918. [CrossRef]

92. Khalid, S.; Shahid, M.; Bibi, I.; Sarwar, T.; Shah, A.H.; Niazi, N.K. A review of environmental contamination and health risk assessment of wastewater use for crop irrigation with a focus on low and high-income countries. Int. J. Environ. Res. Public Health 2018, 15, 895. [CrossRef] [PubMed]

93. Helmecke, M.; Fries, E.; Schulte, C. Regulating water reuse for agricultural irrigation: Risks related to organic micro-contaminants. Environ. Sci. Eur. 2020, 32, 1-10. [CrossRef]

94. Boretti, A.; Rosa, L. Reassessing the projections of the world water development report. NPJ Clean Water 2019, 2, 1-6. [CrossRef]

95. Maktabifard, M.; Zaborowska, E.; Makinia, J. Achieving energy neutrality in wastewater treatment plants through energy savings and enhancing renewable energy production. Rev. Environ. Sci. Bio/Technol. 2018, 17, 655-689. [CrossRef]

96. Fróna, D.; Szenderák, J.; Harangi-Rákos, M. The Challenge of Feeding the World. Sustainability 2019, 11, 5816. [CrossRef]

97. Ishangulyyev, R.; Kim, S.; Lee, S.H. Understanding food loss and waste-Why are we losing and wasting food? Foods 2019, 8, 297. [CrossRef]

98. Hall, C.; Dawson, T.; Macdiarmid, J.; Matthews, R.; Smith, P. The impact of population growth and climate change on food security in Africa: Looking ahead to 2050. Int. J. Agric. Sustain. 2017, 15, 124-135. [CrossRef]

99. Cosgrove, W.J.; Loucks, D.P. Water management: Current and future challenges and research directions. Water Resour. Res. 2015, 51, 4823-4839. [CrossRef]

100. Béné, C.; Oosterveer, P.; Lamotte, L.; Brouwer, I.D.; de Haan, S.; Prager, S.D.; Talsma, E.F.; Khoury, C.K. When food systems meet sustainability-Current narratives and implications for actions. World Dev. 2019, 113, 116-130. [CrossRef]

101. Chaudhary, A.; Gustafson, D.; Mathys, A. Multi-indicator sustainability assessment of global food systems. Nat. Commun. 2018, 9 , 1-13. [CrossRef] [PubMed]

102. Miner, K.J.; Rampedi, I.T.; Ifegbesan, A.P.; Machete, F. Survey on Household Awareness and Willingness to Participate in E-Waste Management in Jos, Plateau State, Nigeria. Sustainability 2020, 12, 1047. [CrossRef]

103. Law, K.L. Plastics in the marine environment. Annu. Rev. Mar. Sci. 2017, 9, 205-229. [CrossRef] [PubMed]

104. Kirchherr, J.; Reike, D.; Hekkert, M. Conceptualizing the circular economy: An analysis of 114 definitions. Resour. Conserv. Recycl. 2017, 127, 221-232. [CrossRef]

105. Reike, D.; Vermeulen, W.J.; Witjes, S. The circular economy: New or refurbished as CE 3.0?-Exploring controversies in the conceptualization of the circular economy through a focus on history and resource value retention options. Resour. Conserv. Recycl. 2018, 135, 246-264. [CrossRef]

106. Xi-Liu, Y.; Qing-Xian, G. Contributions of natural systems and human activity to greenhouse gas emissions. Adv. Clim. Chang. Res. 2018, 9, 243-252. [CrossRef]

107. Lelieveld, J.; Klingmüller, K.; Pozzer, A.; Burnett, R.; Haines, A.; Ramanathan, V. Effects of fossil fuel and total anthropogenic emission removal on public health and climate. Proc. Natl. Acad. Sci. USA 2019, 116, 7192-7197. [CrossRef]

108. Nota, G.; Nota, F.D.; Peluso, D.; Toro Lazo, A. Energy Efficiency in Industry 4.0: The Case of Batch Production Processes. Sustainability 2020, 12, 6631. [CrossRef]

109. Hunter, P.R.; MacDonald, A.M.; Carter, R.C. Water supply and health. PLoS Med. 2010, 7, e1000361. [CrossRef] [PubMed] 